\title{
Effectiveness of educational programs on reducing the burden of caregivers of elderly individuals with dementia: a systematic review
}

\author{
Camila Manuela Marim ${ }^{1}$ \\ Valter Silva ${ }^{2}$ \\ Mônica Taminato ${ }^{3}$ \\ Dulce Aparecida Barbosa ${ }^{4}$
}

\begin{abstract}
Objective: This study's objective was to analyze the effectiveness of educational and support programs for caregivers on reducing their burden. Method: The method used was a systematic review. The following were searched; MEDLINE, LILACS, Embase, Cochrane, Web of Science, SciELO and CINAHL. Results: Seven randomized clinical studies were included. These studies compared an educational program with standard care delivery, assessing the burden of caregivers through the Zarit Burden Interview. After the analysis of sensitivity, four studies were grouped in the meta-analysis showing a statistically significant reduction in caregiver burden among the participants of educational and support programs. Conclusion: The evidence obtained in this study suggests that educational and support programs have a positive impact on the reduction of caregiver burden when compared to standard care. Therefore, the inclusion of these programs in institutions providing care to the elderly is effective and should be encouraged. These programs should also share non-pharmacological management strategies for the behavioral and psychological symptoms of dementia.
\end{abstract}

Descriptors: Dementia; Caregivers; Aged; Geriatric Nursing.

\footnotetext{
${ }^{1}$ Master's Student, Escola Paulista de Enfermagem, Universidade Federal de São Paulo, Brazil.

2 Master's Student, Universidade Federal de São Paulo, Brazil.

${ }^{3}$ Doctoral Student, Escola Paulista de Enfermagem, Universidade Federal de São Paulo, Brazil.

${ }^{4}$ PhD, Associate Professor, Escola Paulista de Enfermagem, Universidade Federal de São Paulo, Brazil.
}

Corresponding Author:

Dulce Aparecida Barbosa

Universidade Federal de São Paulo. Escola Paulista de Enfermagem

Rua Napoleão de Barros, 754

Vila Clementino

CEP: 04024-002, São Paulo, SP, Brasil

E-mail: dulce.barbosa@unifesp.br 


\section{Efetividade de programas de educação e suporte na redução da sobrecarga de cuidadores de idosos com demência: revisão sistemática}

Objetivo: o objetivo deste estudo foi analisar a efetividade de programas de educação e suporte de cuidadores na redução de sua sobrecarga. Método: foi realizada uma revisão sistemática com consulta as bases Medline, Lilacs, Embase, Cochrane, Web of Science, SciELO e CINAHL. Resultados: foram incluídos sete ensaios clínicos randomizados que comparavam o programa de educação ao cuidado usual, avaliando a sobrecarga do cuidador através da escala Burden Interview de Zarit. Após análise de sensibilidade, quatro estudos foram agrupados na metanálise, mostrando maior redução na sobrecarga do cuidador entre participantes de programas de educação e suporte, com significância estatística. Conclusão: as evidências, neste estudo, mostram que programas de educação e suporte são favoráveis para a redução da sobrecarga do cuidador quando comparados ao cuidado usual. Dessa forma, a inclusão desses programas em instituições voltadas para a assistência de idosos é efetiva e deve ser estimulada. Pode-se inferir ainda que esses programas devam contemplar o compartilhamento de estratégias de manejo não farmacológico dos sintomas psicológicos e comportamentais das demências.

Descritores: Demência; Cuidadores; Idoso; Enfermagem Geriátrica.

\section{Efectividad de programas educativos en la sobrecarga de cuidadores de pacientes con diagnóstico de demencia: revisión sistemática}

Objetivo: El objetivo de este estudio fue analizar la eficacia de programas de educación y apoyo a cuidadores para reducir su sobrecarga. Método: El método utilizado fue una revisión sistemática. Consultamos el MEDLINE, LILACS, Embase, Cochrane, CINAHL y Web of Science. Resultados: Se incluyeron los ensayos controlados aleatorios que compararon el programa de educación con la atención habitual, con evaluación de la carga del cuidador a través de la Escala de Zarit Burden. Tras el análisis de sensibilidad, cuatro estudios se combinaron en un metaanálisis, que muestra una mayor reducción de la carga del cuidador entre los participantes de los programas educativos y de apoyo, con significación estadística. Conclusión: La evidencia en este estudio indica que los programas educativos y de apoyo son favorables para la reducción de la carga del cuidador. La inclusión de este tipo de programas en las instituciones dedicadas al cuidado de los ancianos es eficaz y debe fomentarse. Se puede inferir que estos programas deben incluir el intercambio de estrategias de manejo no-farmacológico para los síntomas conductuales y psicológicos de la demencia.

Descriptores: Demencia; Cuidadores; Anciano; Enfermería Geriátrica.

\section{Introduction}

Population aging in Brazil has been increasingly evident throughout recent decades, i.e. the elderly population has been growing faster than other age groups. According to the census published by the Brazilian Institute of Geography and Statistics (IBGE) in 2002, the population over 60 years-old had increased $35.6 \%$ between 1999 and that year, with this age group coming to represent $7.9 \%$ of the Brazilian population. The census went on to estimate that within 25 years the elderly population in Brazil would reach 14536029 in absolute terms, showing a tendency to double ${ }^{(1)}$. This tendency of growth has been confirmed by recent figures, which show that this age group has already exceeded $10 \%$ of the total population (2). The incidence and prevalence of dementia increases exponentially with age, doubling every five years after the age of 60 . In Brazilian studies, the average prevalence of dementia in the elderly population was $7.1 \%{ }^{(3-4)}$, which results from two key factors: rising life expectancy in Brazil and improved survival rates of individuals affected by dementia as a result of better care and more effective treatment. 
It is estimated that $6 \%$ of the population over 65 and $30 \%$ of individuals older than 90 have some form of dementia ${ }^{(5)}$. After the age of 65 , 33\% women and $20 \%$ of men will go on to develop some form of dementia at some stage of their life ${ }^{(6)}$.

The International Classification of Diseases, ICD-10, and the Diagnostic and Statistical Manual of Mental Disorders, DSM-IV, indicate that a diagnosis of dementia should be made based on the symptoms of decline of memory and of other brain functions such as language, praxis, the capacity to recognize and identify objects, abstraction, organization and planning skills. Moreover, these capacities must be diminished severely enough to interfere with the individual's ability to perform the activities of daily life. As this disorder develops, functional decline sets in, which in turn forces families to assume functions previously carried out by the elderly person. This can have negative consequences on the quality of life of family caregivers and lead to the situation where caregivers become not only partners in care, but also potential users of social services and the healthcare system $^{(7)}$.

Behavioral symptoms such as agitation, dysphoria, apathy, irritability, delusions, hallucinations and disinhibition, among others, are commonly observed in patients with dementia and tend to increase in frequency and intensity as the disorder progresses ${ }^{(8)}$. The more marked the changes in a sufferer's behavior are, the more burdened the caregiver is in their daily routine, making behavioral changes one of the determining factors for early institutionalization of elderly patients with dementia(9). These behavioral and psychological symptoms of dementia (BPSD) are associated with a worse prognosis, higher costs and increased morbidity among caregivers ${ }^{(10)}$.

In addition to these symptoms, two important stress predictors for family caregivers are the amount of time spent caring for the dementia sufferer and whether or not the caregiver lives with the patient. Other factors that are also strongly associated with higher levels of stress among caregivers are the severity of functional loss and the extent of cognitive impairment ${ }^{(11)}$.

Overburdened caregivers have higher rates of depression, anxiety and psychotropic drug use, in addition to worse overall health and lower levels of life satisfaction. In a population study, elderly people who took care of spouses who suffered from dementia and who reported greater levels of burden were shown to have a higher risk of mortality ${ }^{(12)}$. Against this background, this study aims to examine the evidence available in the literature on how effective education and support programs are in reducing the burden of the caregivers of patients with dementia.

\section{Method}

This study consists of a systematic review with a meta-analysis, and follows the methodology proposed by the Cochrane Collaboration (13-14). We included studies regardless of the language used or form of publication they took.

For studies to be included in our review, they had to meet the following inclusion criteria: use randomized clinical trials with blinded assessments; analyze interventions which provided interdisciplinary education and support for caregivers of patients with dementia and; have results which evaluated the scale of caregiver burden using the Zarit Burden Interview.

The study was submitted to the Ethics and Research Committee of the Federal University of São Paulo, UNIFESP, and was approved and considered riskfree under protocol number 0137/11.

\section{Search strategies used to select studies}

Relevant studies were selected through electronic searches of PubMed (January 1966 to December 2011), LILACS (January 1982 to December 2011), EMBASE (January 1985 to December 2011), SciELO (June 1998 to December 2011), The Cochrane Library (including the Cochrane Controlled Trials Register, housed in the Cochrane Library 2010), Web of Science (1945 to December 2011) and CINAHL (January 1981 to December 2011).

We also searched the www.controledtrials.com database and abstracts of conference papers, references to review articles, published systematic reviews and references to randomized clinical trials identified through December 2011

The search strategy we used was developed for MEDLINE via PubMed, as shown in Figure 1, and adapted to all other databases we considered. 
((((““Dementia”[Mesh] OR (DementiasAmentia) OR (AmentiasSenile Paranoid Dementia) OR (Dementias, Senile Paranoid) OR (Paranoid
Dementia, Senile) OR (Paranoid Dementias, Senile) OR (Senile Paranoid Dementias) OR (Familial Dementia) OR (Dementia, Familial) OR
(Dementias, Familial) OR (Familial Dementias))) OR (“Alzheimer Disease”[Mesh] OR (Disease, Alzheimer) OR (Alzheimer's Disease) OR
(Disease, Alzheimer's) OR (Primary Senile Degenerative Dementia) OR (Dementia, Alzheimer Type) OR (Alzheimer Type Dementia) OR (Senile
Dementia, Alzheimer Type) OR (Alzheimer Type Senile Dementia) OR (Dementia, Primary Senile) OR (Degenerative) OR (Dementia, Senile) OR
(Dementias, Senile) OR (Senile Dementia) OR (Senile Dementias) OR (Dementia, Presenile) OR (Dementias, Presenile) OR (Presenile Dementia)
OR (Presenile Dementias) OR (Alzheimer Disease, Late Onset) OR (Late Onset al.zheimer Disease) OR (Alzheimer's Disease, Focal Onset) OR
(Focal Onset al.zheimer's Disease) OR (Acute Confusional Senile Dementia) OR (Senile Dementia, Acute Confusional) OR (Alzheimer Disease,
Early Onset) OR (Early Onset al.zheimer Disease) OR (Presenile Alzheimer Dementia) OR (Alzheimer Dementia, Presenile) OR (Dementia,
Presenile Alzheimer))) OR (“Caregivers”[Mesh] OR (Caregiver) OR (Care Givers) OR (Care Giver) OR (Carers) OR (Carer) OR (Family Caregivers)
OR (Caregiver, Family) OR (Caregivers, Family) OR (Family Caregiver) OR (Spouse Caregivers) OR (Caregiver, Spouse) OR (Caregivers,
Spouse) OR (Spouse Caregiver)))) AND (((randomized controlled trial[pt]) OR (controlled clinical trial[pt]) OR (randomized[tiab]) OR (placebo[tiab])
OR (drug therapy[sh]) OR (randomly[tiab]) OR (trial[tiab]) OR (groups[tiab])) AND (humans[mh]))

Figure 1 - Search strategy developed for MEDLINE (via PubMed)

\section{Selection of studies}

The papers were read by two independent reviewers (MWC and MT) to see if they fulfilled the inclusion criteria. They assessed the titles and abstracts of all of the studies, which were identified as being interesting. We obtained full copies of all relevant articles.

A third reviewer (DAB) was asked to give a deciding opinion if there was a question mark or disagreement as to whether the study should be included or not. Where more than one publication of the same study was identified, we included the one that was the most recent or that had the most complete information.

\section{Data Extraction}

We used the Cochrane method to stratify the studies, initially according to their design type and subsequently to their outcomes.

\section{Assessment of methodological quality}

In this study, two independent researchers carried out a non- blind assessment of methodological quality, defined as the confidence that the design and / or reporting of the study were bias free. According to renowned authors ${ }^{(15)}$ the key to randomized clinical trials is: the generation of the allocation sequence, the concealment of this allocation and the use of masking methods; i.e. ensuring the assessment is double-blind. As for non-pharmacological interventions, in which double-blind intervention is not possible, studies were considered eligible if they had a blind evaluation and included the other criteria of a randomized clinical trial.

\section{Statistical analysis}

The treatment effect was measured by the mean difference (MD) (post-intervention value minus the baseline value). Following procedures described in the literature ${ }^{(16)}$, we used variance imputation of the average difference of the continuous data and transformed this into the standard deviation, with a 95\% confidence interval. Heterogeneity was assessed using I2 and T2 tests and a visual inspection of the forest graph. When I2> 50\% and T2> 1, accompanied by a statistical significance $(P<0.10)$, we considered that there was significant heterogeneity and investigated the reason. A sensitivity analysis was used to evaluate the robustness of the results. Meta-analysis of fixed and random effects were calculated using the RevMan software (version 5.1.7).

\section{Results}

After an extensive literature search, we found 1053 studies (after removing cross references). In a pre-selection, reviewers identified 68 studies that met the inclusion criteria. After reading the articles in full, seven studies were selected. This process is described in Figure 2.

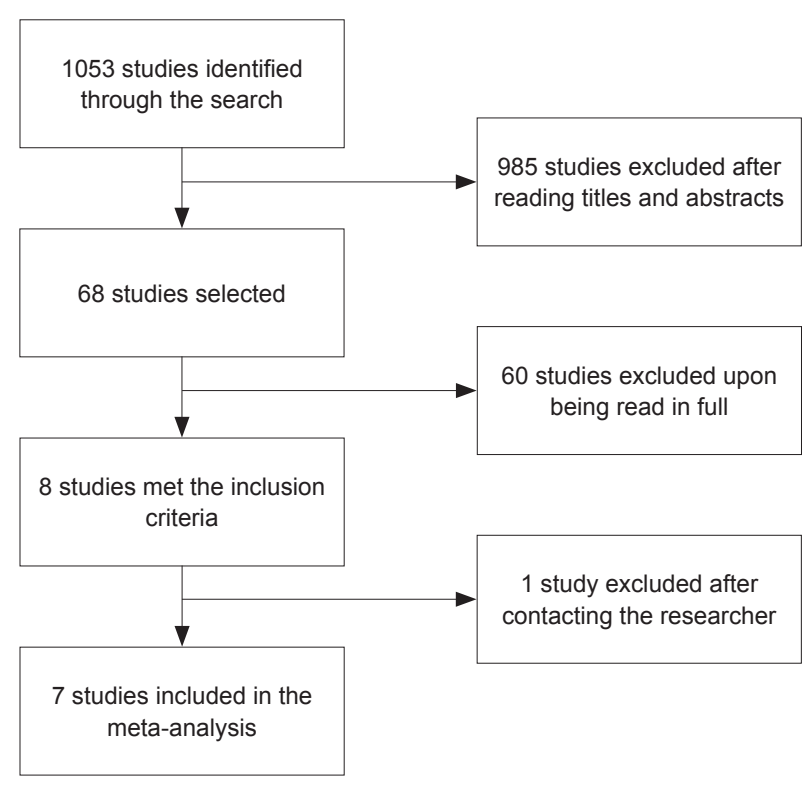

Figure 2 - Flowchart for identifying and selecting studies 
The selected studies were: Carrasco et al. $2009^{(17),}$ Fortinsky et al. 2009(18), Gavrilova et al. 2009(19), Guerra et al. 2009(20), Hérbert et al.1994(21), Hérbert et al. 2003 (22) and Rotrou et al. 2011(23), as described in Figure 3.

All selected studies were considered to have low risk of bias according to the criteria in the Cochrane
Handbook ${ }^{(13)}$. The blinding of participants or evaluator was considered as low risk because all of these studies used blinded evaluation and it is impossible to blind participants in studies of non-pharmacological intervention.

\begin{tabular}{|c|c|c|c|c|c|}
\hline Título & Autores & $\begin{array}{l}\text { País } \\
\text { Ano }\end{array}$ & $\begin{array}{l}\text { Delineamento do } \\
\text { estudo }\end{array}$ & Intervenções & Desfecho \\
\hline $\begin{array}{l}\text { Effectiveness of a } \\
\text { psychoeducational intervention } \\
\text { program in the reduction of } \\
\text { caregiver burden in Alzheimer's } \\
\text { disease patients' caregivers }\end{array}$ & $\begin{array}{l}\text { Manuel Martín- } \\
\text { Carrasco, Manuel } \\
\text { Franço Martín, Carmelo } \\
\text { Pelegrín Valero, Pedro } \\
\text { Roy Millán, Celso } \\
\text { Iglesias García et al. }\end{array}$ & $\begin{array}{l}\text { Espanha } \\
2008\end{array}$ & $\begin{array}{l}\text { ECR, multicêntrico, } \\
\text { prospectivo, } \\
\text { seguimento de } 115 \\
\text { cuidadores por } 10 \\
\text { meses }\end{array}$ & $\begin{array}{l}\text { Programa } \\
\text { educativo } \\
\text { semanal } \\
\text { individual versus } \\
\text { cuidado usual }\end{array}$ & $\begin{array}{l}\text { Zarit } \\
\text { GI=62,0 (14,9) } \\
=>54,0(15,9) \\
G C=58,4(15,9)=>60,5 \\
(16,6)\end{array}$ \\
\hline $\begin{array}{l}\text { Dementia care consultation for } \\
\text { family caregivers: Collaborative } \\
\text { model linking an Alzheimer's } \\
\text { association chapter with primary } \\
\text { care physicians }\end{array}$ & $\begin{array}{l}\text { Richard H. Fortinsky, } \\
\text { Martin Kuuldorff, } \\
\text { Alison Kleppinger, Lisa } \\
\text { Kenyon-Pesce }\end{array}$ & $\begin{array}{l}\text { EUA } \\
2009\end{array}$ & $\begin{array}{l}\text { ECR, multicêntrico, } \\
\text { prospectivo, } \\
\text { seguimento de } 84 \\
\text { cuidadores por } 12 \\
\text { meses }\end{array}$ & $\begin{array}{l}\text { Programa } \\
\text { educativo } \\
\text { mensal individual } \\
\text { versus cuidado } \\
\text { usual }\end{array}$ & $\begin{array}{l}\text { Zarit } \\
\text { GI=30,42 (26,30-34,53) } \\
=>26,18(21,81-30,55) \\
\text { GC=36,02 (30,71-41,33) } \\
=>30,57(25,03-36,10)\end{array}$ \\
\hline $\begin{array}{l}\text { Helping carers to care - the 10/66 } \\
\text { Dementia Research Group's } \\
\text { randomized control trial of a } \\
\text { caregiver intervention in Russia }\end{array}$ & $\begin{array}{l}\text { Svetlana I. Gavrilova, } \\
\text { Cleusa P.Ferri, } \\
\text { Natalya Mikhaylova, } \\
\text { Olga Sokolova, Sube } \\
\text { Banerjee, Martin Price }\end{array}$ & $\begin{array}{l}\text { Russia } \\
2011\end{array}$ & $\begin{array}{l}\text { ECR, multicêntrico, } \\
\text { prospectivo, } \\
\text { seguimento de } 60 \\
\text { cuidadores por } 6 \\
\text { meses }\end{array}$ & $\begin{array}{l}\text { Programa } \\
\text { educativo } \\
\text { semanal } \\
\text { individual versus } \\
\text { cuidado usual }\end{array}$ & $\begin{array}{l}\text { Zarit } \\
\text { GI=31,3 (10,5) } \\
=>30,3(12,8) \\
\mathrm{GC}=32,3(12,8)=>32,7 \\
(12,9)\end{array}$ \\
\hline $\begin{array}{l}\text { Helping carers to care: the } 10 / 66 \\
\text { Dementia Research Group's } \\
\text { randomized control trial of a } \\
\text { caregiver intervention in Peru }\end{array}$ & $\begin{array}{l}\text { Mariella Guerra, } \\
\text { Cleusa P. Ferri, } \\
\text { Magaly Fonseca, Sube } \\
\text { Banerjee, Martin Prince }\end{array}$ & $\begin{array}{l}\text { Peru } \\
2011\end{array}$ & $\begin{array}{l}\text { ECR, multicêntrico, } \\
\text { prospectivo, } \\
\text { seguimento de } 58 \\
\text { cuidadores por } 6 \\
\text { meses }\end{array}$ & $\begin{array}{l}\text { Programa } \\
\text { educativo } \\
\text { semanal } \\
\text { individual versus } \\
\text { cuidado usual }\end{array}$ & $\begin{array}{l}\text { Zarit } \\
\text { GI=19,4 (13,9) } \\
=>17,6(11,8) \\
\text { GC=21,2 }(9,5)=>21,2 \\
(9,5)\end{array}$ \\
\hline $\begin{array}{l}\text { Efficacy of a psychoeducative } \\
\text { group program for caregivers of } \\
\text { demented persons living at home: } \\
\text { a randomized controlled trial }\end{array}$ & $\begin{array}{l}\text { Réjean Hérbert, Louise } \\
\text { Lévesque, Jean } \\
\text { Vézima, Jean-Pierre } \\
\text { Lavoie, Francine } \\
\text { Ducharme et al. }\end{array}$ & $\begin{array}{l}\text { Canadá } \\
2003\end{array}$ & $\begin{array}{l}\text { ECR multicêntrico, } \\
\text { prospectivo, } \\
\text { seguimento de } 144 \\
\text { participantes por } 4 \\
\text { meses }\end{array}$ & $\begin{array}{l}\text { Programa } \\
\text { educativo } \\
\text { semanal em } \\
\text { grupo versus } \\
\text { cuidado usual }\end{array}$ & $\begin{array}{l}\text { Zarit } \\
\text { GI=42,47 (14,63) } \\
=>40,07(14,84) \\
\mathrm{GC}=41,44(15,16) \\
=>41,25(16,55)\end{array}$ \\
\hline $\begin{array}{l}\text { Efficacy of a support group } \\
\text { programme for caregivers } \\
\text { of demented patients in the } \\
\text { community: a randomized } \\
\text { controlled trial }\end{array}$ & $\begin{array}{l}\text { Réjean Hérbert, } \\
\text { Gilbert Leclerc, Gina } \\
\text { Bravo, Diane Girouard, } \\
\text { Richard Lefrançois }\end{array}$ & $\begin{array}{l}\text { Canadá } \\
1994\end{array}$ & $\begin{array}{l}\text { ECR, prospectivo, } \\
\text { seguimento de } 45 \\
\text { participantes por } 8 \\
\text { meses }\end{array}$ & $\begin{array}{l}\text { Programa } \\
\text { educativo } \\
\text { semanal em } \\
\text { grupo versus } \\
\text { cuidado usual }\end{array}$ & $\begin{array}{l}\text { Zarit } \\
\text { GI=36,08 }(16,93) \\
=>34,90(17,71) \\
\text { GC=40,77(14,80) } \\
=>36,06(16,41)\end{array}$ \\
\hline $\begin{array}{l}\text { Do patients diagnosed with } \\
\text { Alzheimer's disease benefit } \\
\text { from a psycho-educational } \\
\text { programme for family caregivers? } \\
\text { A randomised controlled study }\end{array}$ & $\begin{array}{l}\text { Jocelyne de Rotrou, } \\
\text { Inge Cantegreil, } \\
\text { Véronique Faucounau, } \\
\text { Emilie Wenisch, } \\
\text { Catherine Chausson } \\
\text { et al. }\end{array}$ & $\begin{array}{l}\text { França } \\
2011\end{array}$ & $\begin{array}{l}\text { ECR, multicêntrico, } \\
\text { prospectivo, } \\
\text { seguimento de } 157 \\
\text { cuidadores por } 6 \\
\text { meses }\end{array}$ & $\begin{array}{l}\text { Programa } \\
\text { educativo } \\
\text { semanal em } \\
\text { grupo versus } \\
\text { cuidado usual }\end{array}$ & $\begin{array}{l}\text { Zarit } \\
\text { GI=26,52 (17,03) } \\
=>23,04(14,57) \\
\text { GC=24,30(16,93) } \\
=>22,97(14,19)\end{array}$ \\
\hline
\end{tabular}

* IG - Intervention Group and CG - Control Group

Outcome: Overall Zarit score at baseline (standard deviation) => Overall Zarit score at final follow-up (standard deviation)

Figure 3 - Summary of the characteristics of selected studies

For the meta-analysis of the results obtained from the selected studies, we opted to analyze articles in two subgroups; intention to treat (ITT) or not. The data showed that there is a decrease in caregiver burden, measured by the Zarit Burden Interview scale, between the two groups (Figure 3 ). In the analysis of articles that used ITT, the MD was -1.10 , ranging between -2.25 and 0.05 , with a confidence interval (CI) of $95 \%$. In articles without ITT, the MD was -4.46 , ranging between -15.54 and 6.62 , with a $95 \% \mathrm{CI}$. 


\begin{tabular}{|c|c|c|c|c|c|c|c|c|c|c|}
\hline \\
\hline \multirow{2}{*}{$\begin{array}{l}\text { a) All studies } \\
\text { Study or sub-group }\end{array}$} & \multicolumn{3}{|c|}{ Educational program } & \multicolumn{3}{|c|}{ Standard care } & \multirow{2}{*}{ Weight } & \multirow{2}{*}{$\begin{array}{c}\text { Mean difference } \\
\mathrm{VI} \text { fixed } \mathrm{Cl} 95 \% \\
\end{array}$} & \multirow{2}{*}{\multicolumn{2}{|c|}{$\begin{array}{l}\text { Mean difference } \\
\text { VI fixed CI 95\% }\end{array}$}} \\
\hline & Mean & SD & $\mathbf{n}$ & Mean & SD & $\mathbf{n}$ & & & & \\
\hline \multicolumn{11}{|l|}{ ITT } \\
\hline Hérbert et al, 1994 & -1.18 & 5.00 & 24 & -4.73 & 5.21 & 18 & $12.3 \%$ & $3.55[0.42,6.68]$ & & $\square-$ \\
\hline Rotrou et al, 2011 & 1.33 & 2.58 & 72 & 2.22 & 3.06 & 69 & $15.0 \%$ & $-0.89[-1.83,0.05]$ & $-\square$ & \\
\hline Gavrilova et al, 2009 & -1.00 & 2.86 & 30 & 0.40 & 3.38 & 30 & $14.5 \%$ & $-1.40[-2.98,0.18]$ & $\rightarrow$ & \\
\hline Guerra et al, 2009 & -1.80 & 3.44 & 29 & 0.00 & 2.50 & 29 & $14.5 \%$ & $-1.80[-3.35,-0.25]$ & $\rightarrow-$ & \\
\hline Hérbert et al, 2003 & -2.40 & 2.46 & 72 & -0.19 & 2.65 & 72 & $15.1 \%$ & $-2.21[-3.05,-1.37]$ & $\square$ & \\
\hline Subtotal (IC 95\%) & & & 227 & & & 218 & $71.4 \%$ & $-1.10[-2.25,0.05]$ & $\nabla$ & \\
\hline \multicolumn{11}{|c|}{ Heterogeneity: $\mathrm{Tau}^{2}=1.13 ; \mathrm{Chi}^{2}=14.56, \mathrm{df}=4(P=0.006) ; P=73 \%$} \\
\hline \multicolumn{11}{|c|}{ Test to calculate overall Zarit score: $Z=1.87(P=0.06)$} \\
\hline \multicolumn{11}{|l|}{ No ITT } \\
\hline Fortinsky et al, 2009 & -4.24 & 3.06 & 46 & -5.45 & 3.91 & 20 & $14.1 \%$ & $1.21[-0.72,3.14]$ & & - \\
\hline Carrasco et al, 2009 & -8.00 & 3.29 & 44 & 2.10 & 3.73 & 38 & $14.5 \%$ & $-10.10[-11.63,-8.57]$ & $\rightarrow$ & \\
\hline Subtotal (IC 95\%) & & & 90 & & & 58 & $28.6 \%$ & $-4.46[-15.54,6.62]$ & & \\
\hline \multicolumn{11}{|c|}{ Heterogeneity: Tau $^{2}=63.17 ; \mathrm{Chi}^{2}=80.95, d f=1(P<0.00001) ; P=99 \%$} \\
\hline \multicolumn{11}{|c|}{ Test to calculate overall Zarit score: $Z=0.79(P=0.43)$} \\
\hline Total (IC 95\%) & & & 317 & & & 276 & $100.0 \%$ & $-1.79[-4.27,0.69]$ & & \\
\hline \multicolumn{11}{|c|}{ Heterogeneity: $\mathrm{Tau}^{2}=10.41 ; \mathrm{Chi}^{2}=135.68, \mathrm{df}=6(\mathrm{P}<0.00001) ; \mathrm{P}=96 \%$} \\
\hline Test to calculate overall 2 & rit score: & $z=1.4$ & $=0.1$ & & & & & & $\begin{array}{lll}-10 & -5 & 0\end{array}$ & 510 \\
\hline Test for the difference be & reen sub & roups: & $\mathrm{i}^{2}=0$. & $d f=1(P$ & 0.55), $\mathrm{P}$ & $=0 \%$ & & & $\begin{array}{l}\text { Favorable to } \\
\text { educational } \\
\text { programs }\end{array}$ & $\begin{array}{r}\text { Favorable to } \\
\text { usual care }\end{array}$ \\
\hline \multicolumn{11}{|l|}{ b) Sensibility analysis } \\
\hline \multirow{2}{*}{ Study or sub-group } & \multicolumn{3}{|c|}{ Educational program } & \multicolumn{3}{|c|}{ Standard care } & & Mean difference & \multicolumn{2}{|c|}{ Mean difference } \\
\hline & Mean & SD & $\mathrm{n}$ & Mean & SD & $\mathrm{n}$ & Weight & VI fixed $\mathrm{Cl} 95 \%$ & \multicolumn{2}{|c|}{ VI fixed $\mathrm{Cl} 95 \%$} \\
\hline Rotrou et al, 2011 & 1.33 & 2.58 & 72 & 2.22 & 3.06 & 69 & $33.7 \%$ & $-0.89[-1.83,0.05]$ & - 머 & \\
\hline Gavrilova et al, 2009 & -1.00 & 2.86 & 30 & 0.40 & 3.38 & 30 & $11.7 \%$ & $-1.40[-2.98,0.18]$ & $\rightarrow$ & \\
\hline Guerra et al, 2009 & -1.80 & 3.44 & 29 & 0.00 & 2.50 & 29 & $12.3 \%$ & $-1.80[-3.35,-0.25]$ & $\rightarrow-$ & \\
\hline Hérbert et al, 2003 & -2.40 & 2.46 & 72 & -0.19 & 2.65 & 72 & $42.3 \%$ & $-2.21[-3.05,-1.37]$ & $\square$ & \\
\hline Total (IC 95\%) & & & 203 & & & 200 & $100.0 \%$ & $-1.62[-2.16,-1.08]$ & $\diamond$ & \\
\hline \multicolumn{11}{|c|}{ Heterogeneity: $\mathrm{Chi}^{2}=4.38, d f=3(P=0.22) ; P=31 \%$} \\
\hline \multicolumn{9}{|c|}{ Test to calculate overall Zarit score: $Z=5.85(P<0.00001)$} & $\begin{array}{lll}-10 & -5 & 0\end{array}$ & 510 \\
\hline & & & & & & & & & $\begin{array}{l}\text { Favorable to } \\
\text { educational } \\
\text { programs }\end{array}$ & $\begin{array}{r}\text { Favorable to } \\
\text { usual care }\end{array}$ \\
\hline
\end{tabular}

Figure 4 - Mean difference between Zarit score at baseline and post-intervention: education program versus usual care

In both subgroups there was statistically significant heterogeneity $(p<0.10)$. However, articles that used ITT, despite showing lesser effects than those without ITT, were less heterogeneous (Figure 4). In the first subgroup, the studies that evaluated with ITT, heterogeneity was $73 \%, p=0.006$. This was a result of including an earlier study in this analysis, Hérbert et al.. $1994^{(21)}$, in which the MD of the control group was higher than that of the intervention group $(-4.73$ and -1.18 , respectively). In this study, the content of this intervention did not cover strategies for the nonpharmacological management of BPSD. The same author published a further article on the topic nine years later, which is also included in this meta-analysis (22), in which he described a new intervention with an more incisive focus on behavior disorders and better results in reducing caregiver burden.

In the second subgroup, without ITT, we found heterogeneity of $99 \%$ with $p<0.00001$. In this, the Carrasco et al., 2009 study (17), with a MD of -10.10 between the case and control groups, and the negative outcome of the Fortinsky et al., 2009 study $^{(16)}$, which showed a MD of 1.2 between groups, were particularly significant. In both studies, there were clinical and statistical differences among caregivers in the intervention group (IG) and control group (CG), which may explain the heterogeneity observed in Figure 2 due to the sample being skewed by a larger number of losses in a single group, as occurred in this study.

In the Fortinsky study, caregivers in the CG were younger and included fewer males than in the IG. The average age of the IG was 64.8 (14.8) and $37 \%$ 
of the participants were men, whereas the GC had an average age of 57.7 (16.4) and a lower proportion of men (20\%). Losses in the IG were expressive, with $33 \%$ of dementia patients being institutionalized during the study, compared to only $6 \%$ of the CG.

In the Carrasco et al., study the inverse was true: caregivers in the IG were younger and more predominantly male. The average age of the IG was 55 (13.3) with $27.3 \%$ of caregivers being male, compared to an average age of 61.6 (13.8) and 35\% male CG. There was a $36.7 \%$ loss in the CG and $20 \%$ loss in the IG.

In order to reduce the heterogeneity caused by the previously cited articles, we conducted a sensitivity analysis excluding them; Hérbert et al. 1994(21), due to the difference in intervention content, and Fortinsky 2009(18) and Carrasco 2008 ${ }^{(17)}$, due to the differences in the population studied. Excluding these studies, the results became more robust and with accepfigure heterogeneity $(31 \%$ with P-0, 22), supporting intervention based on educational and support programs $(p<0.00001)$.

\section{Discussion}

Asimilarmeta-analysis on psychosocial interventions for caregivers of patients with dementia, conducted in 2003, also grouped nonrandomized studies that evaluated outcomes on various scales of psychological symptoms; depression, quality of life, adjustment and burden. Their analysis showed discrete results in terms of caregivers' knowledge, coping strategies and social support and their impact on psychological morbidity, especially in reducing the symptoms of depression. The authors stressed that, despite the limitations of the analysis due to the variety of measurement techniques and population compositions of the selected studies, they saw potential in psychosocial interventions and suggested further studies be undertaken with greater scientific rigor, using similar inclusion criteria and conducted over longer periods of time(24).

In 2007, a new review on the subject also grouped together studies with a variety of outcomes but analyzed their results separately. It included only randomized clinical trials and concluded that, at that time, there was no evidence on the uniform effectiveness of interventions, which were based on information and caregiver support (25).

A recent systematic review of the impact of group interventions on caregiver burden grouped together the outcomes of burden, depression, anxiety and quality of life, among others and included both randomized and non-randomized studies. They included studies on various types of intervention, excluding those which were not conducted in person or which offered exclusively physical activities or occupational therapy. Of the 37 articles selected, 25 found a significant difference in at least one of the outcomes addressed and, according to the authors, related to caregiver burden. However, the authors pointed out the need for studies with more appropriate methodological design and better descriptions and standardization of the intervention performed (26).

A recent study showed that caregivers tend to have a more negative assessment of the quality of life of elderly patients with Alzheimer's disease than the sufferers themselves (27). This negative perception of the patient's quality of life points to a trend of greater caregiver stress associated with the disease, as analyzed in this study.

The studies included in this systematic review that were not favorable to intervention did not mention non-pharmacological strategies for managing symptoms in the proposed interventions ${ }^{(18,21)}$. This may have been a factor contributing to a lack of impact on caregiver burden, since the BPSD are strongly associated with higher burden among caregivers. Fortinsky opted for a less uniform style of intervention, in which a care plan was organized on a monthly basis depending on the problems/necessities brought up by the caregivers. This was in contrast to the other interventions which, while encouraging the active participation of the caregivers, had pre-planned programs to follow. Hérbert, on the other hand, in his later study published in 2003, changed the intervention style to focus more acutely on behavioral disorders, as noted in the discussion section of his article. He demonstrated how this type of intervention had a positive impact on caregiver burden (22).

Both the Fortinsky and Carrasco studies found an inverse relationship of age, suggesting that older caregivers may have a greater tendency towards overburden. However, in the other studies, which showed no statistical difference between the control and intervention groups, we observed average ages closer to those of the upper age groups of these two studies. The exception was in the study of Guerra (20), whose caregivers had an average age of 50 .

The inverse relationship of gender, which showed a possible trend suggesting that male caregivers present higher levels of burden, was not observed by 
other studies included. In the studies of Guerra (20) and Hérbert ${ }^{(22)}$, less than $20 \%$ of both groups were male caregivers. In the studies Gavrilova (19) and Rotrou (23) meanwhile, just over $30 \%$ of the caregivers were male. Thus, we did not find enough evidence to support the hypothesis that younger caregivers and / or females respond better to educational support programs or have less of a tendency to become overburdened while caring for dementia patients. Other studies, not included in this systematic review because they were not randomized trials, also showed a statistically significant positive impact of educational programs in reducing caregiver burden (28-31).

\section{Conclusion}

In this systematic review we selected only randomized controlled trials, which looked at the effects of education and support programs for caregivers. We found evidence to support this type of intervention as being more effective than usual care in reducing the burden (assessed using the Zarit Burden Interview) of caregivers of patients with dementia.

\section{Implications for practice}

The evidence obtained in this study suggests that interdisciplinary education and support programs for caregivers can help to reduce the burden of individuals who care for patients with dementia.

Thus, the inclusion of such programs in institutions devoted to the care of the elderly can be beneficial and should be encouraged. It can be inferred that these programs should also include the sharing of non-pharmacological management strategies for the behavioral and psychological symptoms of dementia.

\section{References}

1. Censo Demográfico. Rio de Janeiro: IBGE; 2002. Anual.

2. World Health Organization (WHO).[Internet]. World health statistics 2012. [acesso 1 ago 2012]; Disponível em http://www.who.int/gho/publications/world_health_ statistics/EN_WHS2012_

Full.pdf.

3. Montano MB, Koening AM, Ramos LR. Prevalência de demência em uma coorte de idosos da comunidade. Arq Neuro-Psiquiatria 2001;59:2.

4. Herrera E Jr, Carameli P, Nitrini R. Estudo epidemiológico populacional de demência na cidade de
Catanduva, estado de São Paulo, Brasil. Rev Psiquiatria Clín. 1998;25:70-3.

5. Lobo A, Launer LJ, Fratiglioni L, Andersen K, Di Carlo A, Breteler MM, et al. Prevalence of dementia and major subtypes in Europe: a collaborative study of populationbased cohorts. Neurology 2000;54:S4-S9.

6. Ott A, Breteler MMB, Harskamp F, Stijnen T, Hofman A. Incidence and risk of dementia: the Rotterdam study. Am J Epidemiol. 1998;147:547-80.

7. Gonçalves LHT, Costa MAM; Martins , Nassar SM, Zunino R. The family dynamics of elder elderly in the context of Porto, Portugal. Rev. Latino-Am. Enfermagem. June $2011 ; 19(3)$ :458-66.

8. Lyketsos CG, Steinberg M, Tschanz JT, Norton MC, Steffens DC, Breitner JCS. Mental and behavioral disturbances in dementia: Findings from the cachas county study on memory and aging. Am J Psychiatry. 2000;157:708-14.

9. Rinaldi P, Spazzafumo L, Mastrifortil R, P. Mattioli1, Marvardi M, Polidori M C, et al. Predictors of high level of burden and distress in caregivers of demented patients: results of na Italian multicenter study. Int J Geriatr Psychiatry. 2005;20:168-74.

10. Tatsch MF, Bottino CM, Azevedo D, Hototian SR, Moscoso MA, Folquitto JC, et al. Neuropsychiatric symptoms in Alzheimer disease and cognitively impaired, nondemented elderly from a community-based sample in Brazil: prevalence and relationship with dementia severity. Am J Geriatr Psychiatry 2006;14:438-45.

11. Cassis SVA, Karnakis T, Quadrante ACR, Curiati JAE, Magaldi RM. Correlação entre o estresse do cuidador e as características clínicas do paciente portador de demência. Rev Bras Medicina 2008;283-87.

12. Schulz R, Beach S. Caregiving as a risk factor for mortality: Caregiver Health Effects Study. J Am Med Assoc. 1999;282:2215-9.

13. Higgins JPT, Gren S, editors. Cochrane Handbook for Systematic Reviews of Intervention 5.0.1. In Cochrane Library, issue 4, Chickester, UK: John Wiley; 2005.

14. Medina EU, Pailaquilén RMB. A revisão sistemática e sua relação com a prática baseada na evidência em saúde. Rev. Latino-Am. Enfermagem. [periódico na Internet], jul-ago 2010 [acesso $8 \mathrm{dez} 2012$ ]; 18(4):[08 telas]. Disponível em: http://www.scielo.br/pdf/rlae/ v18n4/pt_23.pdf.

15. Jüni $P$, Altman DG, Egger M. Systematic reviews in health care: Assessing the quality of controlled clinical trials. BMJ. 2001;323:42-6.

16. Follmann D, Elliott P, Suh I, Cutler J. Variance imputation for overviews of clinical trials with continuous 
response. J Clin Epidemiol. 1992;45(7):769-73.

17. Carrasco MM, Martín MF, Valero CP, Millan PR, Garcia CI, Montalbán SR, et al. Effectiveness of a psychoeducational intervention program in the reduction of caregiver burden in Alzheimer's disease patients'care. Int J Geriatric Psychiatry. 2009;24:489-99.

18. Fortinsky RH, Kulldorff M, Kleppinger A, KenyonPesce L. Dementia care consultation for family caregiver: collaborative model linking as Alzheimer's association chapter with preimary care physicians. Aging Mental Health. 2009;13(2):162-70.

19. Gravilova SI, Ferri CP, Mikhaylova N, Sokolova O, Banerjee S, Prince M. Helping carers to care - the 10/66 Dementia Research Group's randomized control trial of a caregiver intervention in Russia. Int J Geriatric Psychiatry. 2009;24:347-54.

20. Guerra $M$, Ferri CP, Fonseca $M$, Banerjee $S$, Prince $M$. Helping carers to care: the 10/66 Dementia Research Group's randomized control trial of a caregiver intervention in Peru. Rev Bras Psiquiatria. 2011;33(1):47-54.

21. Hérbert R, Leclerc G, Bravo G, Girouard D, Lefrançois R. Efficacy of a support group programme for caregivers of demented patients in the community: a randomized controlled trial. Arch Gerontol Geriatrics. 1994;18:1-14. 22. Hérbert R, Lévesque L, Vézina J, Lavoie JP, Ducharme F, Gendron C, et al. Efficacy of a psychoeducative group program for caregivers of demented persons living at home: a randomized controlled trial. J Gerontol. 2003;58B(1):S58-S67.

23. Rotrou J, Cantegreil I, Faucounau V, Wenisch E, Chausson $C$, Jegou D, et al. Do patiens diagnosed with Alzheimer's disease benefit from a psycho-educational programme for family caregivers? A randomized controlled study. Int J Geriatric Psychiatry. 2011;26:833-42.

24. Brodaty $H$, Green A, Koschera A. Meta-Analysis of psychosocial interventions for caregivers of people with dementia. JAGS. 2003;51:1-8.

25. Thompson CA, Spilsbury K, Hall J, Birks Y, Barnes C, Adamson J. Sistematic review of information and support interventions for caregivers of people with dementia. BMC Geriatrics 2007;7:18.

26. Santos RL, Sousa MFB, Brasil D, Dourado M. Intervenções de grupo para sobrecarga de cuidadores de pacientes com demência: uma revisão sistemática. Rev Psiq Clin. 2011;38(4):161-7.

27. Inouye $\mathrm{K}$, Pedrazzani ES, Pavarini SC, Toyoda

CY. Quality of life of elderly with alzheimer's disease: a comparative study between the patient's and the caregiver's report. Rev. Latino-Am. Enfermagem. Feb 2010;18(1):26-32.

28. Javadpour A, Ahmadzadeh L, Bahredar MJ. Na educative support group for female family caregivers: impact on caregivers psychological distress and patient's neuropsychiatry symptoms. Int J Geriatr Psychiatry. 2008;24:469-71.

29. Negovanska V, Hergueta T, Guichart-Gomez E, Dubois $B$, Sarazin $M$, Bungener C. Bénéfice d'un programme cognitivo-comportemental et pluridisciplinaire de prise em charge de la maladie d'Alzheimer sur I'anxiété du conjoint: étude française ELMMA. Revue Neurologique. 2011;167:114-22.

30. Gelmini G, Morabito B, Braidi G. Educational and formative training reduce stress in the caregivers of demented patients. Arch Gerontol Geriatr. 2009;1:119-24. 31. Hepburn KW, Tornatore J, Center B, Ostwald SW Dementia family caregiver training: affecting beliefs about caregiving and caregiver outcomes. JAGS. 2001;49:450-7. 